\title{
Analisis Efisiensi Puskesmas di Kabupaten Sumbawa Tahun 2015
}

\author{
Binar Dwiyanto Pamungkas, Wahyunadi, M. Firmansyah \\ Program Pascasarjana Universitas Mataram \\ Program Studi Ilmu Ekonomi \\ E-mail: binardwiyantopamungkas@yahoo.com
}

Diterima: 2 Mei 2016; Disetujui: 20 September 2016; Dipublikasikan: 4 November 2016

Permalink/DOI: http://dx.doi.org/10.17977/um002v8i22016p183

\begin{abstract}
The focus of this study is measuring relative efficiency of 23 public health centers in Sumbawa regency in 2015, by using non parametric approach Data EnvelopmentAnalysis (DEA). DEA is chosen because it is able to handle more input and output variables. This study uses output oriented model. Input variables consist of numbers of medical staf, numbers of other medical staf, number of capitation funds, operational funds health. Output variables consist of numbers of visitor, Case Detection Rate TBC, safe motherhood, infant's imunization coverage, percentage of child under five's weighting, and coverage of active family planning. The results are 18 public health centers classified as technically efficient and the remaining classified as technically inefficient in 2015 For the public health centers which are technically inefficient can be improved by increasing output variable based on DEA.
\end{abstract}

Keywords: Relative efficiency, Public health center, DEA JEL Classification: C14, D61

\section{PENDAHULUAN}

Kesehatan merupakan hak azasi seperti terdapat pada UUD 1945 pasal 28H ayat 1 dan UU No 23 tahun 1992. Dalam Undang-Undang Nomor 23 tahun 1992 tentang Kesehatan ditetapkan bahwa kesehatan adalah keadaan sejahtera dari badan, jiwa dan sosial yang memungkinkan setiap orang hidup produktif secara sosial dan ekonomi. Pembangunan kesehatan harus dipandang sebagai suatu investasi untuk meningkatkan kualitas sumber daya manusia. Kesehatan adalah salah satu komponen utama selain pendidikan dan pendapatan dalam pengukuran Indeks Pembangunan Manusia. Sehat memungkinkan sebuah bangsa dengan daya tahan yang tinggi dan berkontribusi positif dalam arena bangsa-bangsa di dunia. Agar pembangunan berhasil diperlukan Sumber Daya Manusia yang sehat, yang berasal dari keluarga sehat dan komunitas sportif (Razali, 2012). Kesehatan selain merupakan tujuan prioritas juga merupakan input sentral dalam pembangunan ekonomi dan pengurangan kemiskinan. Input sentral yang dimaksud adalah apabila terjadi peningkatan investasi dalam bidang kesehatan akan menghasilkan peningkatan pendapatan di negara-negara berpendapatan rendah.

Desentralisasi pada dasarnya adalah penataan mekanisme pengelolaan kebijakan dengan kewenangan yang lebih besar diberikan kepada daerah agar penyelenggaraan pemerintah dan pelaksanaan pembangunan lebih efektif dan efisien (Lena, 2007). Belanja Kesehatan merupakan salah satu belanja pembangunan, yang merupakan pengeluaran yang bertujuan untuk pembiayaan proses perubahan dan bersifat menambah modal masyarakat baik dalam bentuk 
pembangunan fisik maupun non fisik (Putri, 2015). Efisiensi pengeluaran belanja daerah diartikan ketika setiap rupiah yang dibelanjakan oleh pemerintah daerah menghasilkan kesejahteraan masyarakat yang paling optimal (Kurnia, 2006).

Berbagai bentuk lembaga pelayanan kesehatan masyarakat sudah ada di Indonesia misalnya, rumah sakit, poliklinik, dan pusat kesehatan masyarakat (puskesmas). Dari ketiga lembaga tersebut, puskesmas merupakan lembaga yang paling tepat karena memberikan pelayanan kesehatan yang sejalan dengan pendekatan sehat. Hal ini dikarenakan selain menjalankan fungsi kuratif, puskesmas juga mempunyai peran dalam kegiatan preventif dan promotif Trisnantoro (2009), yang dapat dilihat dari 3 fungsi puskesmas seperti yang disebutkan dalam Keputusan Menteri Kesehatan RI Nomor 128/Menkes/SK/II/ 2004 tentang Kebijakan Dasar Puskesmas, yaitu pusat penggerak pembangunan dan berwawasan kesehatan, pusat pemberdayaan keluarga dan masyarakat dan pusat pelayanan kesehatan strata pertama.

Pelayanan kesehatan yang diberikan oleh puskesmas bertujuan untuk meningkatkan derajat kesehatan masyarakat di wilayah cakupan pelayanan puskesmas tersebut. Agar dapat memberikan pelayanan yang maksimal maka diperlukan sumber daya yang memadai. Dalam UU Nomor 23 tahun 1992 tentang Kesehatan disebutkan bahwa sumber daya kesehatan merupakan semua perangkat keras dan perangkat lunak yang diperlukan sebagai pendukung penyelenggaraan upaya kesehatan, meliputi: tenaga kesehatan, sarana kesehatan, perbekalan kesehatan, pembiayaan kesehatan, pengelolaan kesehatan, penelitian dan pengembangan kesehatan.

Jumlah puskesmas di Kabupaten Sumbawa adalah 25 unit, maka dengan jumlah penduduk tahun 2014 sebesar 436.599 jiwa, maka secara rata-rata setiap 1 Puskesmas dapat melayani sebesar 17.464 jiwa (BPS, 2014). Peningkatan kapasitas pelayanan kesehatan masyarakat Kabupaten Sumbawa dilakukan dengan optimalisasi dan penambahan fasilitas kesehatan yaitu pembangunan/ pengembangan sarana dan prasarana kesehatan lainnya. Persebaran sarana pelayanan kesehatan puskesmas di Kabupaten Sumbawa secara rata-rata bahwa semua kecamatan memiliki puskesmas dan setiap desa memiliki pustu/poskesdes.

Secara menyeluruh Rasio jumlah dokter umum yang tersebar di seluruh puskesmas Kabupaten Sumbawa 31 orang terhadap jumlah penduduk 436.599 masih jauh dari standar system pelayanan terpadu (Dok. Lakip. Kab. Sumbawa, 2014), akan tetapi dalam penempatannya jumlah Dokter umum, Dokter gigi, Perawat dan Bidan di puskesmas di setiap kecamatan akan disesuaikan dengan jumlah penduduk wilayah kerja puskesmas tersebut. Rasio dokter per jumlah penduduk menunjukkan tingkat pelayanan yang dapat diberikan oleh dokter dibandingkan jumlah penduduk yang ada. Standar system pelayanan kesehatan terpadu, idealnya satu orang dokter melayani 2.500 penduduk atau 4 orang dokter melayani 10.000 penduduk (Dok. Lakip. Kab. Sumbawa, 2014).untuk mengatasi kekurangan tenaga medis,disiasati dengan rujukan horizontal, puskesmas merujuk ke puskesmas, sehingga beberapa puskesmas dijadikan puskesmas satelit untuk bisa merujuk selain itu dilakukan pemberdayaan dokter PTT dan bidan PTTdaerah (Idrianti, 2014).

Kinerja manajemen puskesmas diukur oleh 2 (dua) konsepsi utama yaitu efisiensi dan efektivitas (Handoko, 2015). Jika efisiensi lebih memfokuskan diri pada proses pemanfaatan, penghematan, dan pemberdayaan masukan (input) 
sumber daya, maka efektivitas lebih memfokuskan pada output dan outcome atau hasil kinerja puskesmas yang diharapkan. Efisiensi terkait dengan hubungan antara output pelayanan kesehatan dengan sumber daya yang digunakan untuk menghasilkan output dan outcome (Handoko, 2015).

Pendapat Razali (2012) Secara rata-rata, puskesmas yang efisien menghasilkan output yang lebih besar dibandingkan puskesmas tidak efisien. Berikutnya pendapat Akazili dkk (2008) di Ghana inefisien terjadi selain output yang tidak maksimal juga karena adanya penggunaan sumber daya yang tidak perlu/berlebihan. Alvarado (2007) berpendapat efisien akan tercapai dengan meningkatkan/memaksimalkan output.

Menurut Osei dkk (2005) di Ghana anggaran yang relatif besar pada puskesmas tidak selalu dapat membantu puskesmas tersebut mencapai kondisi yang efisien, strategi dan promosi kesehatan yang harus ditingkatkan untuk mencapai skor efisien. Oleh karena itu diperlukan kebijakan yang mengkaji efisiensi puskesmas dalam pencapaian tingkat hasil, untuk itu diperlukan pengaturan yang lebih berkombinasi yang berorientasikan hasil.

Perbedaan tingkat keberhasilan puskesmas tersebut apakah semata-mata hanya karena secara rata-rata puskesmas efisien menghasilkan output yang lebih besar dibandingkan puskesmas inefisien, apakah selain output yang tidak maksimal inefisien terjadi karena adanya sumberdaya yang tidak perlu/berlebihan, anggaran yang relative besar tidak menjamin puskesmas mencapai kondisi yang efisien, strategi dan promosi kesehatan yang harus ditingkatkan untuk mencapai skor efisien?.

Berdasarkan hasil penelitian yang telah dijelaskan tersebut, pengukuran efisiensi sebenarnya tidak akan menghadapi banyak kendala jika puskesmas hanya memiliki satu input dan satu output untuk proses produksi. Namun hal tersebut jarang dijumpai karena puskesmas memerlukan multi input dan menghasilkan multi output. Pengukuran afisiensi teknis yang multi input dan multi output diharapkan mampu member nuansa baru pada pengukuran kinerja puskesmas dan dapat menjelaskan kinerja puskesmas secara riil.

Penelitian tentang efisiensi puskesmas sudah banyak dilakukan oleh para ahli di seluruh dunia, sebagaimana penelitian yang dilakukan oleh Alkazili dkk (2008); Alvarado (2007), dan Osei dkk. (2005). Namun variabel input dan output yang digunakan berbeda, jumlah obyek penelitian berbeda, serta jangka waktu penelitian yang berbeda. Jika pada penelitian sebelumnya hanya menggunakan jangka waktu 1 tahun penelitian saja.

Puskesmas yang mencapai target pelayanan berarti mampu mengelola sumber daya dengan baik sehingga dapat menyelenggarakan program kegiatan secara maksimal. Kemampuan puskesmas dalam pengelolaan sumber daya dapat mencerminkan tingkat efisiensi puskesmas. Efisiensi adalah rasio antara output dengan input. Secara umum, suatu unit dapat dikatakan efisien apabila menggunakan sejumlah input yang lebih sedikit dibandingkan dengan jumlah input unit-unit lainnya, namun dapat menghasilkan jumlah output yang sama. Atau dengan kata lain, suatu unit dikatakan efisien jika unit tersebut menggunakan jumlah input yang sama dengan unit-unit lainnya, tetapi dapat menghasilkan unit output yang lebih besar. Input puskesmas adalah ketersediaan sumber daya, sedangkan yang menjadi output adalah kegiatan pelayanan kesehatan yang diselenggarakan oleh puskesmas. Perbandingan antara output dengan input inilah 
yang menunjukkan tingkat efisiensi puskesmas-puskesmas di Kabupaten Sumbawa.

Efisiensi sering diartikan bagaimana suatu perusahaan dapat berproduksi dengan biaya serendah mungkin, tetapi tidak sekedar itu efisiensi juga menyangkut pengelolaan hubungan input dan output yaitu bagaimana mengalokasikan faktorfaktor produksi yang tersedia secara optimal untuk dapat menghasilkan output yang maksimal (Abidin, 2009). Pada pengukuran efisiensi ekonomi, harga tidak dapat dianggap sudah ditentukan tetapi harga dapat dipengaruhi oleh kebijakan makro (Rusydiana, 2003).

Keberadaan puskesmas memiliki tugas yang sangat berat yaitu memberikan pelayanan kesehatan dasar, menyeluruh, paripurna, dan terpadu bagi seluruh penduduk yang tinggal di wilayah kerja puskesmas. Program dan upaya kesehatan yang diselenggarakan oleh puskesmas merupakan program pokok (public health essential) yang wajib, namun puskesmas saat ini ketersediaan sumber daya puskesmas sangat terbatas. Dari latar belakang dan penjelasan di atas, penulis merumuskan permasalahan yaitu: (1) Bagaimanakah tingkat efisiensi relatif puskesmas di Kabupaten Sumbawa Tahun 2015?, (2)Apa yang menjadi sumber ketidak efisienan?, (3) Bagaimanakah kontribusi masing-masing variabel input dan output dalam mencapai kondisi efisien?

\section{KAJIAN PUSTAKA}

\section{Teori Produksi}

Secara umum, produksi dapat diartikan sebagai kegiatan optimalisasi dari faktor-faktor produksi seperti, tenaga kerja, modal, dan lain-lainnya oleh perusahaan untuk menghasilkan produk berupa barang-barang dan jasa-jasa (Sukirno, 1994). Secara teknis, kegiatan produksi dilakukan dengan mengombinasikan beberapa input untuk menghasilkan sejumlah output. Dalam pengertian ekonomi, produksi didefinisikan sebagai usaha manusia untuk menciptakan atau menambah daya atau nilai guna dari suatu barang atau benda untuk memenuhi kebutuhan manusia (Sukirno, 1994).

Berdasarkan pada kepentingan produsen, tujuan produksi adalah untuk menghasilkan barang yang dapat memberikan laba. Tujuan tersebut dapat tercapai, jika barang atau jasa yang diproduksi sesuai dengan kebutuhan masyarakat. Oleh karena itu, dapat dikatakan bahwa sasaran kegiatan produksi adalah melayani kebutuhan masyarakat atau untuk memenuhi kebutuhan hidup masyarakat secara umum (Boediono, 2013).Kegiatan produksi melibatkan dua variabel yang mempunyai hubungan fungsional atau saling memengaruhi, yaitu (Boediono, 2013) berapa output yang harus diproduksi, dan berapa input yang akan dipergunakan.

Dengan demikian, yang disebut fungsi produksi adalah hubungan fungsional atau sebab akibat antara input dan output. Dalam hal ini input sebagai sebab, dan output sebagai akibat. Atau input sebagai variabel bebas dan output sebagai variabel tak bebas. Input produksi dikenal juga dengan faktor-faktor produksi, dan ouput produksi dikenal juga dengan jumlah produksi.

Fungsi produksi merupakan suatu fungsi atau persamaan yang menyatakan hubungan antara tingkat output dengan tingkat penggunaan input-input. Hubungan antara jumlah output $\mathrm{Q}$ dengan jumlah input yang dipergunakan dalam produksi $\mathrm{X}_{1}, \mathrm{X} 2, \mathrm{X} 3, \ldots \mathrm{Xn}$, secara matematis dapat dituliskan sebagai berikut (Boediono, $2013 ; 64)$ : 


$$
\begin{aligned}
& \mathrm{Q}=\text { output } \\
& \mathrm{X}=\text { input }
\end{aligned}
$$$$
\mathrm{Q}=\mathrm{f}(\mathrm{X} 1, \mathrm{X} 2, \mathrm{X} 3, \ldots \mathrm{Xn})
$$

Ketika input-input produksi terdiri dari capital, labour, resources dan technology maka persamaan produksi menjadi sebagai berikut (Sukirno, 1994;194):

$$
\mathrm{Q}=\mathrm{f}(\mathrm{C}, \mathrm{L}, \mathrm{R}, \mathrm{T})
$$

$\mathrm{Q}=$ Quantity, atau jumlah barang yang dihasilkan

$\mathrm{f}=$ Fungsi, atau simbol persamaan fungsional

$\mathrm{C}=$ Capital, atau modal atau sarana yang digunakan

$\mathrm{L}=$ Labour, tenaga kerja

$\mathrm{R}=$ Resources, sumber daya alam

$\mathrm{T}=$ Technology, teknologi dan kewirausahaan

Persamaan tersebut menjelaskan bahwa output dari suatu produksi merupakan fungsi atau dipengaruhi atau akibat dari input. Artinya setiap barang yang dihasilkan dari produksi akan tergantung pada jenis/macam dari input yang digunakan. Perubahan yang terjadi pada input akan menyebabkan terjadinya perubahan pada output.

Coelli \& Rao (2005) mendefinisikan produktifitas sebagai rasio dari berbagai output yang diproduksi berdasarkan berbagai input yang digunakan. Dua konsep yang biasa digunakan untuk mengukur suatu kinerja dan pemanfaatan sumber daya adalah produktifitas dan efisiensi.

Dua konsep ini sering digunakan sebagai padanan untuk mengatakan bahwa perusahaan A lebih produktif disbanding perusahaan B, kemudian dipercayai secara umum bahwa perusahaan A lebih efisien. Dengan demikian, produktifitas adalah suatu ukuran deskriptif tentang kinerja, sedangkan efisiensi adalah suatu ukuran bersifat normatif. Dengan menggunakan dasar analisis diatas dapat dipahami, bahwa fungsi produksi puskesmas menunjukkan hubungan teknis yang mempertautkan input atau factor produksi yang berkait dengan sumber daya puskesmas dan hasil produksinya atau output yang berkait dengan pelayanan puskesmas. Kegiatan tersebut memerlukan proses dalam kondisi efisien.

\section{Teori Efisiensi}

Pada teori ekonomi terdapat dua jenis efisiensi, yaitu efisiensi ekonomi (economic efficiency) dan efisiensi teknik (technical efficiency). Efisiensi ekonomi mempunyai gambaran ekonomi makro, sedangkan efisiensi teknik memiliki gambaran ekonomi mikro. Pengukuran efisiensi teknik hanya untuk teknik dan hubungan operasional dalam proses penggunaan input menjadi output. Pada pengukuran efisiensi ekonomi, harga tidak dapat dianggap sudah ditentukan tetapi harga dapat dipengaruhi oleh kebijakan makro (Rusydiana, 2003). Rusydiana, 2003) mengatakan bahwa dalam sudut pandang perusahaan dikenal tiga macam efisiensi, yaitu:

Technical Efficiency yang merefleksikan kemampuan perusahaan untuk mencapai level output yang optimal dengan menggunakan tingkat input tertentu. Efisiensi ini mengukur proses produksi dalam menghasilkan sejumlah output tertentu dengan menggunakan input seminimal mungkin. Dengan kata lain, suatu proses produksi dikatakan efisien secara teknis apabila output dari suatu barang tidak dapat lagi ditingkatkan tanpa mengurangi output dari barang lain. 
Allocative Efficiency, merefleksikan kemampuan perusahaan dalam mengoptimalkan penggunaan inputnya dengan struktur harga dan tekhnologinya. Terminologi efisiensi Pareto sering disamakan dengan efisiensi alokatif untuk menghormati ekonom Italia Vilfredo Pareto yang mengembangkan konsep efficiency inexchange. Efisiensi Pareto mengatakan bahwa input produksi digunakan secara efisien apabila input tersebut tidak mungkin lagi digunakan untuk meningkatkan suatu usaha tanpa menyebabkan setidak-tidaknya keadaan suatu usaha yang lain menjadi lebih buruk. Dengan kata lain, apabila input dialokasikan untuk memproduksi output yang tidak dapat digunakan atau tidak diinginkan konsumen, hal ini berarti input tersebut tidak digunakan secara efisien (Pertiwi, 2007; Sutawijaya \& Puji, 2009).

Economic Efficiency, yaitu kombinasi antara efisiensi teknikal dan efisiensi alokatif. Efisiensi ekonomis secara implisit merupakan konsep least cost production. Untuk tingkat output tertentu, suatu perusahaan produksinya dikatakan efisien secara ekonomi jika perusahaan tersebut menggunakan biaya dimana biaya per unit dari output adalah yang paling minimal, Dengan kata lain, untuk tingkat output tertentu, suatu proses produksi dikatakan efisien secara ekonomi jika tidak ada proses lainnya yang dapat digunakan untuk memproduksi tingkat output tersebut pada biaya per unit yang paling kecil (Kalirajan \& Shand, 1999).

Suatu perusahaan dikategorikan efisien secara teknis jika menghasilkan output maksimal dengan sumber daya tertentu. Dapat pula didefinisikan dengan memproduksi jumlah output tertentu dengan menggunakan sumber daya yang minimal (Putri dan Lukviarman, 2009), sedangkan perusahaan dalam efisiensi ekonomis menghadapi kendala terbatasnya input sehingga perusahaan harus bisa memaksimalkan output dengan sejumlah input yang tersedia.

Seorang produsen harus mengkombinasikan faktor produksi seefisien mungkin agar input yang digunakan paling rendah (least cost combination). Dualitas antara produksi dan biaya selain menghasilkan produk yang maksimal juga memenuhi persyaratan kombinasi input dengan biaya yang paling rendah (Nugroho, 2004)

Pengukuran efisiensi dengan menggunakan pendekatan frontier sudah digunakan selama 40 tahun lebih (Coelli, 1996). Metode utama yang menggunakan linier programming dan metode ekonomterika adalah: 1) Data Envelopment Analysis; dan 2) Stokastic Frontier.

Pengukuran efisiensi modern ini pertama kali dirintis oleh Farrell (1957), bekerja sama dengan Debreu dan Koopmans, dengan mendefinisikan suatu ukuran yang sederhana untuk mengukur efisiensi suatu perusahaan yang dapat memperhitungkan input yang banyak. Efisiensi yang dimaksudkan oleh Farrell terdiri dari efisiensi teknis (technical efficiency) yang merefleksikan kemampuan dari suatu perusahaan untuk memaksimalkan output dengan input tertentu, dan efisiensi alokatif (allocative efficiency) yang merefleksikan kemampuan dari suatu perusahaan yang memanfaatkan input secara optimal dengan tingkat harga yang telah ditetapkan. Kedua ukuran efisiensi ini kemudian dikombinasikan untuk menghasilkan efisiensi ekonomis (total). 


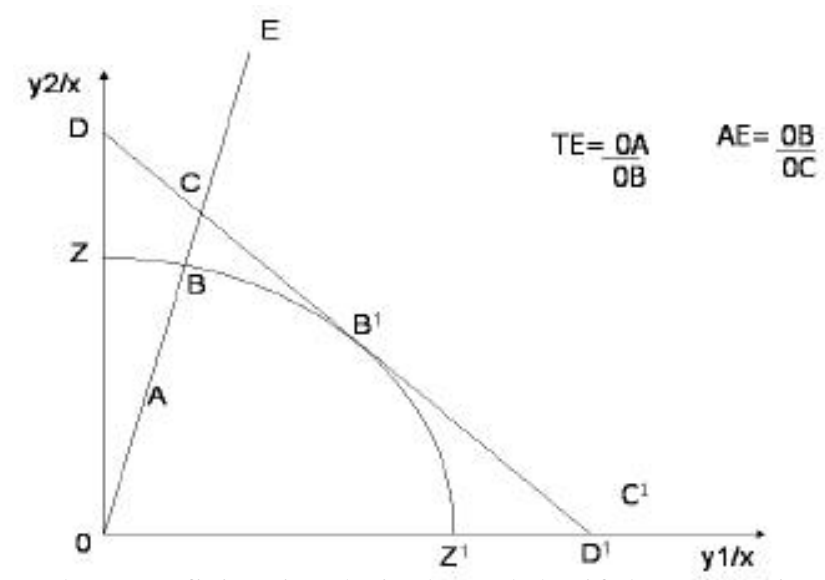

Gambar 1. Efisiensi Teknis dan Alokatif dengan Orientasi Output Sumber: Coelli, 1996; Rusyidiana 2003.

Titik A dan B1 menggambarkan skala efisiensi yang dihasilkan oleh perusahaan A dan B1. Kurva ZZ1 adalah kurva kemungkinan produksi (production possibility curve) yang menunjukkan efisien secara teknis. Kurva DD1 menggambarkan kurva isorevenue (efisien secara alokatif). Titik B dan B1 menggambarkan efisien secara teknikal karena terletak pada isoquant. CB1 efisien secara alokatif karena terletak pada isorevenue DD1. B1 efisien secara teknis dan alokatif. Titik OE menunjukkan kombinasi output yang dihasilkan oleh perusahaan. Titik A merupakan titik inefisieni secara teknis maupun alokatif karena tidak terletak pada ZZ1 dan DD1. AB merupakan inefisien secara teknis yang berarti bahwa output bisa ditingkatkan menjadi B tanpa adanya tambahan input. Penghitungan efisiensiteknis dengan pendekatan output adalah rasio dari OA/OB. Isorevenue adalah garis yang menggambarkan kombinasi output yang dihasilkan oleh perusahaan dengan tingkat pendapatan yang sama. Efisiensi alokatif diperoleh melalui rasio OB/OC. Jika digabungkan, maka menjadi efisiensi ekonomi OA/OB $\mathrm{X} \mathrm{OB} / \mathrm{OC}=\mathrm{OA} / \mathrm{OC}$.

\section{Data Envelopment Analisis (DEA)}

DEA adalah sebuah metode optimasi program matematika yang dipergunakan untuk mengukur efisiensi teknis suatu unit Decision Making Units (DMUs) dan membandingkan secara relatif terhadap DMU lain (Charnes, Cooper \& Banker, 1984). Awalnya metode DEA digunakan oleh Farrel (1957) untuk membandingkan efisiensi relatif dengan sampel petani secara cross section dan terbatas pada satu output yang dihasilkan oleh masing-masing unit sampel. Dalam perkembangannya DEA merupakan alat analisis yang digunakan untukmengukur efisiensi relatif dalam penelitian pendidikan, kesehatan, transportasi, pabrik, maupun perbankan (Sengupta, 2000; Haryadi, 2011).

DEA merupakan pendekatan non-parametrik yang sering banyak dipilih dalam banyak penelitian karena beberapa alasan, meliputi: Efisiensi relatif UKE dalam DEA, juga didefinisikan sebagai rasio dari total ouput tertimbang dibagi total input tertimbang (total weighted output/total weighted input). Inti dari DEA adalah menentukan bobot (weighted) atau timbangan untuk setiap input dan output UKE. Setiap UKE diasumsikan bebas menentukan bobot untuk setiap variabel-variabel input maupun output yang ada, asalkan mampu memenuhi dua kondisi yang disyaratkan (Saleh, 2000). 
Menurut Ramanathan $(2003 ; 20)$ DEA adalah pengembangan programasi linier yang didasarkan pada teknik pengukuran kinerja relatif dari sekelompok unit input dan output. DEA dapat mengatasi keterbatasan yang dimiliki analisis rasio parsial maupun regresi berganda. DEA merupakan prosedur yang dirancang secara khusus untuk mengukur efisiensi relatif suatu decision making unit (DMU) yang menggunakan banyak input maupun output. Dalam DEA efisiensi relative DMU didefinisikan sebagai rasio dari total output tertimbang dibagi total input tertimbangnya.

Pendekatan DEA lebih menekankan kepada melakukan evaluasi terhadap kinerja DMU. Analisis yang dilakukan berdasarkan kepada evaluasi terhadap efisiensi relatif dari DMU yang sebanding. Selanjutnya DMU-DMU yang efisien tersebut akan membentuk garis frontier. Jika DMU berada pada garis frontier, maka DMU tersebut dapat dikatakan efisien relatif dibandingkan DMU yang lain dalam peer group nya. Selain menghasilkan nilai efisiensi masing-masing DMU, DEA juga menunjukkan unit-unit yang menjadi referensi bagi unit-unit yang tidak efisien (Endri, 2008).

Produktifitas dari setiap DMU diukur dengan membandingkan input dan output yang digunakan dengan sebuah titik yang terdapat pada garis yang disebut dengan garis frontir efisien (efficient frontier). Garis tersebut akan mengelilingi atau menutupi (envelop) data dari organisasi yang bersangkutan. Garis frontier efisien ini diperoleh dari unit yang full efficient. Beberapa unit yang berbeda pada garis ini dianggap memiliki nilai produktifitas sama dengan satu $(=1)$, sedangkan unit yang berada di bawah garis frontir efisien memiliki nilai produktifitas lebih kecil dari satu $(<1)$ dan merupakan unit yang inefficient.

Ramanathan (2003) menyebutkan ada dua faktor yang mempengaruhi dalam pemilihan DMU, yaitu: DMU harus merupakan unit-unit yang homogen. Unit-unit tersebut melakukan tugas (task) yang sama, dan memiliki obyektif yang sama. Input dan output yang mencirikan kinerja dari DMU harus identik, kecuali berbeda hanya intensitas dan jumlah/ukurannya (magnitude).

Hubungan antara jumlah DMU terhadap jumlah input dan output kadangkala ditentukan berdasarkan "rule of thumb", yaitu jumlah DMU diharapkan lebih banyak dibandingkan jumlah input dan output dan ukuran sampel seharusnya dua atau tiga kali lebih banyak dibandingkan dengan jumlah keseluruhan input dan output.

Menurut Purwantoro (2004) model DEA setidaknya memiliki tiga keunggulan dibandingkan model lain, yaitu: Model DEA dapat mengukur banyak variabel input dan variabel output, Tidak diperlukan asumsi hubungan fungsional antara variabel-variabel yang diukur, Variabel input dan output dapat memiliki satuan pengukuran yang berbeda

Makmun (2002) berpendapat, walaupun analisis DEA memiliki banyak kelebihan dibandingkan analisis rasio parsial dan analisis regresi, DEA memiliki beberapa keterbatasan, yaitu: DEA mensyaratkan semua input dan output harus spesifik dan dapat diukur (demikian pula dengan analisis rasio dan regresi). Kesalahan dalam memasukkan input dan output akan memberikan hasil yang bias. DEA berasumsi bahwa setiap unit input atau output identik dengan unit lain dalam tipe yang sama. Tanpa mampu mengenali perbedaan-perbedaan tersebut, DEA akan memberi hasil yang bias. Dalam bentuk dasarnya DEA berasumsi constant return to scale (CRS). CRS menyatakan bahwa perubahan proporsional pada semua 
tingkat input akan menghasilkan perubahan proporsional yang sama pada tingkat output. Bobot input dan output yang dihasilkan oleh DEA tidak dapat ditafsirkan dalam nilai ekonomi.

Pertama kalinya model CCR ditemukan oleh Charnes, Cooper dan Rhodes pada tahun 1978. Pada model ini diperkenalkan suatu ukuran efisiensi untuk masing-masing decision making unit (DMU) yang merupakan rasio maksimum antara output yang terbobot dengan input yang terbobot. Masing-masing nilai bobot yang digunakan dalam rasio tersebut ditentukan dengan batasan bahwa rasio yang sama untuk tiap DMU harus memiliki nilai yang kurang dari atau sama dengan satu.

Model CCR dikenal dengan nama constant return to scale (CRS), yaitu perbandingan nilai output dan input bersifat konstan, penambahan nilai input dan output sebanding. Pada model CCR, tidak terdapat syarat convexity constraint, berbeda dengan model Banker-Charnes-Cooper (BCC) yang terdapat syarat convexity constraint. Model matematis DEA-CCR dengan menggunakan program nonlinear untuk DMU ke-k dari sejumlah n DMU adalah sebagai berikut:

Objective function :

efisiensi $=\frac{\sum_{r=1}^{s} U . Y r 0}{\sum_{i=1}^{m} v i X i 0} \leq 1$

Subject to :

Dimana :

$$
=\frac{\sum_{r=1}^{S} U r Y r j}{\sum_{i=1}^{m} V i X i j} \quad \leq 1 ; j=1,2,3, \ldots n
$$

$\mathrm{j}: \mathrm{DMU}, \mathrm{j}=1 \ldots, \mathrm{n}$

$\mathrm{i}$ : input, $\mathrm{I}=1 \ldots, \mathrm{n}$

r: output,r $=1 \ldots, \mathrm{n}$

Data :

$\mathrm{y}_{\mathrm{rj}} \quad$ : nilai output ke-r dari DMU ke-j

$\mathrm{X}_{\mathrm{rj}} \quad$ : nilai input ke-I dari DMU ke-j

Variabel :

$\mathrm{Z}_{\mathrm{k}} \quad$ : efisiensi relative DMUk

$\mathrm{U}_{\mathrm{r}} \quad$ : bobot untuk output $\mathrm{r}$

$\mathrm{V}_{\mathrm{i}} \quad$ : bobot untuk input $\mathrm{i}$

Ada 2 pendekatan dalam CRS model, yaitu:

Model input oriented

Objective function : Min $\theta$

Subject to :

$\sum_{\forall[=1} \lambda j \operatorname{Yrj}-Y k k \geq 0 ; r=1,2, \ldots s$

$$
\theta x_{i k}-\sum_{j=1}^{n} \lambda j X \text { 帄 } j \geq 0 ; i=1,2, \ldots m
$$

Model output oriented

$$
\lambda_{j} \geq 0 \text { (weight dari DMU) ; } j=1,2, \ldots n
$$

Objective function : Max $\varnothing$

Model BCC (Banker, Charnes and Cooper) ini digunakan jika kita berasumsi bahwa perbandingan terhadap input maupun output suatu perusahaan akan mempengaruhi produktifitas yang mungkin tercapai, yaitu VRS (Variabel Returns to Scale). Model Variabel Return to Scale (VRS) digunakan karena adanya kompetisi yang tidak sempurna, keterbatasan dana dan lain-lain. Hal ini menyebabkan DMU tidak bisa untuk beroperasi secara optimal. Oleh karena itu 
Banker, Charnes dan Cooper pada tahun 1984 menyarankan agar model DEA-CRS yang telah menggunakan asumsi bahwa semua DMU beroperasi secara optimal untuk dikembangkan dalam situasi VRS. Model DEA-CRS dapat dengan mudah dikembangkan dalam model DEA-VRS hanya dengan menambah fungsi konveksitas (Convexity Constrain), yaitu:

Sehingga modelnya menjadi:

$$
\sum_{j=1}^{n} \lambda j=1
$$

DEA VRS input oriented

Objective function : Min $\theta$

Subject to :

$$
\begin{aligned}
& \quad \sum_{j=1}^{n} \lambda j Y r j-Y b k \geq 0 ; r=1,2, \ldots s \\
& \quad \theta x_{i k}-\sum_{j=1}^{n} \lambda j X i j \geq 0 ; i=1,2, \ldots m \\
& \sum_{i=1}^{n} \lambda j=1 \\
& \lambda_{j} \geq 0 ; j=1,2, \ldots n
\end{aligned}
$$

\section{METODE}

Penelitian ini adalah penelitian kuantitatif dengan menggunakan metode Data Envelopment Analysis (DEA). DEA merupakan alat analisis yang digunakan untuk mengukur efisiensi relatif masing-masing unit sampel penelitian. Lokasi penelitian adalah puskesmas-puskesmas di Kabupaten Sumbawa. Kabupaten Sumbawa dijadikan lokasi penelitian karena berdasarkan latar belakang diatas capaian indikator kesehatan di Kabupaten Sumbawa sangat bervariasi. Populasi pada penelitian ini adalah 25 puskesmas, dan sampel penelitian dalam penelitian ini berjumlah 23 puskesmas yaitu puskesmas perawatan yang terdapat di Kabupaten Sumbawa.

\section{Ruang Lingkup, Metode Pengumpulan Data dan Variabel Penelitian}

Jenis data yang diperlukan pada penelitian ini adalah data sekunder. Data sekunder untuk input variabel meliputi: Jumlah dana kapitasi yang terlihat dari Dokumen Pelaksanaan Anggaran Satuan Kerja Perangkat Daerah (DIPA SKPD) tahun 2015, dana bantuan operasional kesehatan (BOK) yang tercermin dalam data realisasi dana bantuan operasional kesehatan (BOK) wilayah kabupaten Sumbawa tahun 2015, jumlah tenaga kesehatan medis,dan jumlah tenaga kesehatan lainnya yang tercermin dalam data ketenagakerjaan puskesmas dan data pegawai tidak tetap (PTT) per puskesmas tahun 2015. Selanjutnya variabel output yang terdiri dari: Jumlah kunjungan, cakupan TB Paru BTA, cakupan balita ditimbang, cakupan persalinan yang ditolong tenaga kesehatan, cakupan imunisasi dasar, cakupan KB aktif yang terangkum dalam profil kesehatan kabupaten Sumbawa tahun 2015. Data variabel input dan output diformulasikan kedalam asumsi Variabel Return to Scale yang berorientasi output (output maximization).

Variabel input meliputi (1) Jumlah dana kapitasi adalah dana yang diterima oleh Puskesmas dimanfaatkan seluruhnya untuk (a) pembayaran jasa pelayanan kesehatan dan (b) dukungan biaya operasional pelayanan kesehatan. Dana kapitasi untuk dukungan biaya operasional pelayanan kesehatan dimanfaatkan untuk (a) 
obat, alat kesehatan dan bahan medis habis pakai, dan (b) kegiatan operasional pelayanan kesehatan lainnya. (2) jumlah dana bantuan operasional kesehatan Adalah bantuan dana dari pemerintah melalui Kementerian Kesehatan dalam membantu Pemerintah Daerah Kabupaten/Kabupaten melaksanakan pelayanan kesehatan sesuai Standar Pelayanan Minimal (SPM) Bidang Kesehatan menuju Millennium Development Goals (MDGs) Bidang Kesehatan tahun 2015 melalui peningkatan kinerja puskesmas dan jaringannya serta Poskesdes dan Posyandu dalam menyelenggarakan pelayanan kesehatan yang bersifat promotif dan preventif., (3) jumlah tenaga kesehatan medis adalah tenaga kesehatan yang terdiri dari Dokter Spesialis, Dokter Umum dan Dokter Gigi, (4) jumlah tenaga kesehatan lainnya adalah Tenaga Kesehatan lain yang ada di Puskesmas Kabupaten Sumbawa yaitu Bidan (S1 Bidan, DIII Bidan, Bidan), Perawat (sarjana Keperawatan, DIII Keperawatan, (Lulusan SPK), Tenaga farmasi (Apoteker, Asisten Apoteker), Sanitarian, Teknisi Medis (Analis Laboratorium, Penata Rontgen, Penata Anestesi) Fisioterapis dan Penyuluh Gizi.

Variabel output terdiri dari : (1) Jumlah kunjungan menjadi salah satu output prioritas karena menunjukkan kinerja dan produktifitas pelayanan tenaga kesehatan didalam gedung dalam rangka pelayanan kesehatan dasar dan rujukan. (Kemenkes, 2011), (2) cakupan TB Paru BTA merupakan Persentase Penemuan Pasien baru TB. BTA (positif) atau Case Detection Rate (CDR TB) merupakan salah satu indikator yang ditetapkan Berdasarkan SPM Bidang Kesehatan. Penemuan Pasien TB Paru juga merupakan upaya pencegahan dan pemberantasan penyakit menular, (3) cakupan balita ditimbang Persentase Balita ditimbang menunjukkan pencapaian program perbaikan gizi masyarakat. Indikator ini merupakan komponen penting dalam penentuan Indeks Pembangunan manusia (IPM), (4) cakupan persalinan yang ditolong tenaga kesehatan adalah persentase pertolongan persalinan oleh tenaga kesehatan yang memiliki kompetensi kebidanan. Angka ini menunjukkan keberhasilan pelaksanaan program safe motherhood dan pencegahan komplikasi, (5) cakupan imunisasi dasar merupakan salah satu program pada upaya KIA (Kesehatan Ibu dan Anak) dan keluarga berencana. Program imunisasi ini adalah program dasar lengkap (LIL/Lima Imunisasi Dasar Lengkap) pada bayi meliputi satu dosis BCG, 3 dosis DPT 4, 4 dosis polio, 4 dosis hepatitis B dan 1 dosis campak., (6) cakupan KB aktif Cakupan peserta KB Aktif merupakan indikator untuk melihat mutu pelayanan KB dan partisipasi masyarakat. Peserta KB aktif adalah alat/cara KB yang digunakan oleh Pasangan Usia Subur (PUS), yaitu 15-49 tahun untuk mengatur jumlah kelahiran atau menjarangkan kelahiran.

\section{Data Envelopment Analysis}

DEA dikembangkan oleh Charnes et al. (1978) dan menggunakan linear programming untuk evaluasi komparatif efisiensi DMUs. DEA tujuannya adalah untuk membandingkan sejumlah DMUs melakukan tugas-tugas yang sama dan membedakannya dalam jumlah input yang digunakan dan output yang dihasilkan. Pada dasarnya ada dua model klasik DEA: Constant Return Scale (CRS) model, juga dikenal sebagai CCR (Charnes, Cooper \& Rhodes, 1978) dan Variabel Return Scale (VRS) model, juga dikenal sebagai BCC (Banker, Charnes \& Cooper, 1984). Model pertama mempertimbangkan skala hasil konstan, model kedua mengasumsikan skala hasil variabel tidak ada proposionalitas antara input dan output. Dalam penggunaan DEA pada analisis puskesmas asumsi yang digunakan 
adalah Variabel Return Scale. DMUs, $\mathrm{k}=1, \ldots, \mathrm{n}$, dianggap unit produksi yang menggunakan input $r \mathrm{x}_{\mathrm{ik}} \mathrm{I}=1, \ldots, \mathrm{r}$, untuk menghasilkan output $\mathrm{s} \mathrm{y}_{\mathrm{jk}}, \mathrm{J}=1, \ldots, \mathrm{s}$. Model BCC yang dijelaskan oleh (1) memaksimalkan rasio antara kombinasi linear dari output dan kombinasi linear dari input, dengan kendala bahwa untuk setiap DMUs rasio yang tidak lebih besar dari satu. Jadi, khusus untuk DMUs $h_{o}$ adalah efisiensi; $x_{i o}$ dan $y_{j o}$ adalah input dan output dan $v_{i}$ dan $u_{i j}$ adalah dihitung bobot untuk input dan output.

Memaksimalkan fungsi tujuan:

$\operatorname{Max} \mathrm{h}_{\mathrm{o}}=\frac{\sum_{j=1}^{S} \mathrm{U}_{\mathrm{j}} \mathrm{Y}_{\mathrm{jo}}}{\sum_{i=1}^{r} \mathrm{~V}_{\mathrm{j}} \mathrm{X}_{\mathrm{jo}}}$

Dengan kendala

$$
\begin{aligned}
\frac{\sum_{j=1}^{s} \mathrm{U}_{\mathrm{j}} \mathrm{Y}_{\mathrm{jk}}}{\sum_{i=1}^{r=1} \mathrm{~V}_{\mathrm{j}} \mathrm{X}_{\mathrm{jk}}} \quad \leq 1, \mathrm{k} & =1, \ldots \ldots, \mathrm{n} \\
\mathrm{u}_{\mathrm{j}}, \mathrm{v}_{\mathrm{i}} & \geq 0 \quad \mathrm{~V}_{\mathrm{i}}, \mathrm{j}
\end{aligned}
$$

Setelah beberapa prosedur matematika, model tersebut dapat ditulis ulang, menghasilkan sebuah linear programming seperti pada (2).

Memaksimalkan fungsi tujuan:

$\max$ ho $=\sum_{j=1}^{S} \mathrm{u}_{\mathrm{j}} \mathrm{y}_{\mathrm{jo}}$

Dengan kendala

$\sum_{\mathrm{i}=1}^{\mathrm{r}} \mathrm{V}_{\mathrm{i}} \mathrm{X}_{\mathrm{io}}=1$

$\sum_{j=1}^{S} \mathrm{u}_{\mathrm{j}} \mathrm{Y}_{\mathrm{jk}}-\sum_{i=1}^{r} \mathrm{~V}_{\mathrm{i}} \mathrm{X}_{\mathrm{ik}} \leq 0, \quad \mathrm{k}=1, \ldots \ldots \mathrm{n}$

$\mathrm{u}_{\mathrm{j}}, \mathrm{v}_{\mathrm{i}} \geq 0-\mathrm{V}_{\mathrm{i}, \mathrm{j}}$

Sebagai linear programming untuk masing-masing DMUs, jika kita memiliki $n$ DMUs, $n$ linear programming harus dipecahkan, dengan $r+s$ variabel keputusan. Model hanya disajikan sebagai dasar untuk semua model DEA lainnya. Selain indeks efisiensi, model DEA menghasilkan untuk masing-masing DMUs: variabel bobot, tolak ukur dan target untuk DMUs yang tidak efisien.

\section{HASIL DAN PEMBAHASAN}

Pengukuran efisiensi teknis model DEA dilakukan dengan metode orientasi output dengan menggunakan skala VRS (variabel return to scale). Sesuai uraian teori bab sebelumnya pemilihan skala VRS (variabel return to scale) merupakan model DEA-BCC yang dikembangkan oleh Banker, Charnes, dan Cooper pada tahun 1984 Model ini beranggapan bahwa perusahaan tidak atau belum beroperasi pada skala yang optimal dengan Asumsi bahwa rasio antara penambahan input dan output tidak sama.

Model orientasi output (output-oriented model) yaitu model dimana setiap DMU diharapkan memproduksi sejumlah output terbesar yang memungkinkan dengan sejumlah input tertentu (maksimasi output), dengan demikian DEA output oriented memfokuskan analisis kepada maksimisasi output pada tingkat input dan tantangan kondisi sosial ekonomi tertentu.

Berdasarkan tabel 1 dapat dilihat hasil pengukuran efisiensi dengan menggunakan DEA selama tahun 2015 pada puskesmas di Kabupaten Sumbawa adalah sebagai berikut: sebanyak 18 puskesmas (78.3\%) yang menjadi obyek penelitian memiliki skor $100 \%$ dan yang memiliki skor efisiensi di bawah $100 \%$ sebanyak 5 puskesmas $(21.7 \%$ ) yaitu Moyo Hilir 91\%, Lunyuk 96.14\%, Plampang $92.08 \%$, Unteriwes $96.57 \%$, dan Utan $95.30 \%$. Puskesmas yang mempunyai nilai efisiensi paling rendah adalah puskesmas Moyo Hilir dengan nilai $91 \%$. 
Tabel 1. Skor efisiensi 23 Puskesmas di Kabupaten Sumbawa tahun 2015

\begin{tabular}{|c|c|c|c|}
\hline Puskesmas & 2015 & Puskesmas & 2015 \\
\hline Moyohulu & $100 \%$ & Lunyuk & $96.14 \%$ \\
\hline Moyohilir & $91 \%$ & Marnge & $100 \%$ \\
\hline Alasbarat & $100 \%$ & Moyou & $100 \%$ \\
\hline Alas & $100 \%$ & Orongtelu & $100 \%$ \\
\hline Badas & $100 \%$ & Plmpng & $92.08 \%$ \\
\hline Buer & $100 \%$ & Rhee & $100 \%$ \\
\hline Empang & $100 \%$ & Ropang & $100 \%$ \\
\hline Lantung & $100 \%$ & Sumbawa & $100 \%$ \\
\hline Lape & $100 \%$ & Tarano & $100 \%$ \\
\hline Lbngka & $100 \%$ & Unteriwes & $96.57 \%$ \\
\hline Lenangguar & $100 \%$ & Utan & $95.30 \%$ \\
\hline
\end{tabular}

Lopok $\quad 100 \%$

Sumber: Hasil Olahan DEA, Data sekunder, diolah

Berdasarkan Tabel 2 menunjukkan sumber ketidakefisienan Puskesmas Moyo Hilir pada tahun 2015 (skor 91\%). Faktor-faktor yang menyebabkan puskesmas Moyo Hilir belum mencapai skor efisiensi maksimum dapat dilihat pada penggunaan variabel input dan pencapaian variabel output yang belum mencapai (achieved) 100\%. Pencapaian masing-masing variabel input meliputi: dana bantuan operasional kesehatan (dana BOK) dengan pencapaian $83.9 \%$ tidak mampu mencapai skor efisien karena hasil perhitungan DEA menunjukkan adanya kelebihan dalam mengalokasikan input, jumlah tenaga kesehatan medis (tenakesmed) dengan pencapaian $\mathbf{7 5 . 7 \%}$ tidak mampu mencapai skor efisien karena hasil perhitungan DEA menunjukkan adanya kelebihan dalam mengalokasikan input, jumlah tenaga kesehatan lainnya(tenakeslain) dengan pencapaian $81.3 \%$ tidak mampu mencapai skor efisien karena hasil perhitungan DEA menunjukkan adanya kelebihan dalam mengalokasikan input. Sedangkan penggunaan variabel output belum mencapai (achieved) 100\% yaitu seluruh variabel output meliputi: Jumlah kunjungan, Cakupan TB Paru BTA (BTA), Cakupan balita yang ditimbang (\% Balita), cakupan persalinan ditolong tenaga kesehatan (linakes), Cakupan imunisasi dasar (imunisaid), cakupan KB aktif (KB aktif). Secara keseluruhan variabel output tidak mampu mencapai skor efisien karena hasil perhitungan DEA menunjukkan adanya pencapaian output yang belum maksimal.

Puskesmas Plampang pada tahun 2015 (skor 92.08\%). Faktor-faktor yang menyebabkan puskesmas Plampang belum mencapai skor efisiensi maksimum dapat dilihat pada penggunaan variabel input dan pencapaian variabel output yang belum mencapai (achieved) 100\%. Pencapaian masing-masing variabel input meliputi: dana kapitasi dengan pencapaian $96.6 \%$ tidak mampu mencapai skor efisien karena hasil perhitungan DEA menunjukkan adanya kelebihan dalam mengalokasikan input, dana bantuan operasional kesehatan (dana BOK) dengan pencapaian $76.4 \%$ dimana dana bantuan operasional kesehatan puskesmas Plampang adalah paling besar diantara puskesmas lainnya akan tetapi tidak mampu mencapai skor efisien karena hasil perhitungan DEA menunjukkan adanya kelebihan dalam mengalokasikan input. Sedangkan penggunaan variabel output belum mencapai (achieved) 100\% yaitu seluruh variabel output meliputi: Jumlah kunjungan, Cakupan TB Paru BTA (BTA), Cakupan balita yang ditimbang (\% Balita), cakupan persalinan ditolong tenaga kesehatan (linaskes), Cakupan 
imunisasi dasar (imunisaid), cakupan KB aktif (KBaktif). Secara keseluruhan variabel output tidak mampu mencapai skor efisien karena hasil perhitungan DEA menunjukkan adanya pencapaian output yang belum maksimal.

Puskesmas Utan pada tahun 2015 (skor 95.30\%). Faktor-faktor yang menyebabkan puskesmas Utan belum mencapai skor efisiensi maksimum dapat dilihat pada penggunaan variabel input dan pencapaian variabel output yang belum mencapai (achieved) 100\%. Pencapaian masing-masing variabel input meliputi: dana kapitasi dengan pencapaian 32.2\% dimana dana kapitasi puskesmas Utan adalah paling besar diantara puskesmas lainnya akan tetapi tidak mampu mencapai skor efisien karena hasil perhitungan DEA menunjukkan adanya kelebihan dalam mengalokasikan input, dana bantuan operasional kesehatan (dana BOK) dengan pencapaian $72.3 \%$ tidak mampu mencapai skor efisien karena hasil perhitungan DEA menunjukkan adanya kelebihan dalam mengalokasikan input, jumlah tenaga kesehatan lainnya (tenakeslain) dengan pencapaian $69.7 \%$ tidak mampu mencapai skor efisien karena hasil perhitungan DEA menunjukkan adanya kelebihan dalam mengalokasikan input. Sedangkan penggunaan variabel output belum mencapai (achieved) 100\% yaitu seluruh variabel output meliputi: Jumlah kunjungan, Cakupan TB Paru BTA (BTA), Cakupan balita yang ditimbang (\% Balita), cakupan persalinan ditolong tenaga kesehatan (linaskes), Cakupan imunisasi dasar (imunisaid), cakupan KB aktif (KB aktif). Secara keseluruhan variabel output tidak mampu mencapai skor efisien karena hasil perhitungan DEA menunjukkan adanya pencapaian output yang belum maksimal.

Puskesmas Lunyuk pada tahun 2015 (skor 96.14\%). Faktor-faktor yang menyebabkan puskesmas Lunyuk belum mencapai skor efisiensi maksimum dapat dilihat pada penggunaan variabel input dan pencapaian variabel output yang belum mencapai (achieved) 100\%. Pencapaian masing-masing variabel input meliputi: dana kapitasi dengan pencapaian $75 \%$ tidak mampu mencapai skor efisien karena hasil perhitungan DEA menunjukkan adanya kelebihan dalam mengalokasikan input, dana bantuan operasional kesehatan (dana BOK) dengan pencapaian 92.7\% tidak mampu mencapai skor efisien karena hasil perhitungan DEA menunjukkan adanya kelebihan dalam mengalokasikan input, jumlah tenaga kesehatan medis (tenakesmed) dengan pencapaian 82.9\% tidak mampu mencapai skor efisien karena hasil perhitungan DEA menunjukkan adanya kelebihan dalam mengalokasikan input. Sedangkan penggunaan variabel output belum mencapai (achieved) 100\% yaitu seluruh variabel output meliputi: Jumlah kunjungan, Cakupan TB Paru BTA (BTA), Cakupan balita yang ditimbang (\% Balita), cakupan persalinan ditolong tenaga kesehatan (linaskes), Cakupan imunisasi dasar (imunisaid), cakupan KB aktif (KB aktif). Secara keseluruhan variabel output tidak mampu mencapai skor efisien karena hasil perhitungan DEA menunjukkan adanya pencapaian output yang belum maksimal.

Puskesmas Unteriwes pada tahun 2015 (skor 96.57\%). Faktor-faktor yang menyebabkan puskesmas Unteriwes belum mencapai skor efisiensi maksimum dapat dilihat pada penggunaan variabel input dan pencapaian variabel output yang belum mencapai (achieved) 100\%. Pencapaian masing-masing variabel input meliputi: dana kapitasi dengan pencapaian $67.8 \%$ tidak mampu mencapai skor efisien karena hasil perhitungan DEA menunjukkan adanya kelebihan dalam mengalokasikan input, dana bantuan operasional kesehatan (dana BOK) dengan pencapaian $85 \%$ tidak mampu mencapai skor efisien karena hasil perhitungan DEA 
menunjukkan adanya kelebihan dalam mengalokasikan input, jumlah tenaga kesehatan lainnya (tenakeslain) dengan pencapaian $67.8 \%$ dimana tenaga kesehatan lainnya puskesmas Unteriwes adalah paling besar diantara puskesmas lainnya akan tetapi tidak mampu mencapai skor efisien karena hasil perhitungan DEA menunjukkan adanya kelebihan dalam mengalokasikan input. Sedangkan penggunaan variabel output belum mencapai (achieved) 100\% yaitu seluruh variabel output meliputi: Jumlah kunjungan, Cakupan TB Paru BTA (BTA), Cakupan balita yang ditimbang (\% Balita), cakupan persalinan ditolong tenaga kesehatan (linaskes), Cakupan imunisasi dasar (imunisaid), cakupan KB aktif (KBaktif). Secara keseluruhan variabel output tidak mampu mencapai skor efisien karena hasil perhitungan DEA menunjukkan adanya pencapaian output yang belum maksimal.

Tabel 2. Sumber ketidakefisienan puskesmas tahun 2015

\begin{tabular}{|c|c|c|}
\hline PUSKESMAS & VARIABEL & ACHIEVED \\
\hline \multirow{9}{*}{ MOYO HILIR } & Danabok & $83.9 \%$ \\
\hline & Tenakesmed & $75.7 \%$ \\
\hline & Tenakeslai & $81.3 \%$ \\
\hline & Jumlahkunj & $91.0 \%$ \\
\hline & Bta & $91.0 \%$ \\
\hline & $\%$ Balita & $91.0 \%$ \\
\hline & Linakes & $91.0 \%$ \\
\hline & Imunisasid & $91.0 \%$ \\
\hline & Kbaktif & $85.7 \%$ \\
\hline PUSKESMAS & VARIABEL & ACHIEVED \\
\hline \multirow{9}{*}{ PLAMPANG } & Danabok & $76.4 \%$ \\
\hline & Tenakesmed & $100.0 \%$ \\
\hline & Tenakeslai & $100.0 \%$ \\
\hline & Jumlahkunj & $92.1 \%$ \\
\hline & Bta & $79.5 \%$ \\
\hline & $\%$ Balita & $92.1 \%$ \\
\hline & Linakes & $92.1 \%$ \\
\hline & Imunisasid & $78.9 \%$ \\
\hline & Kbaktif & $89.3 \%$ \\
\hline PUSKESMAS & VARIABEL & ACHIEVED \\
\hline \multirow[t]{10}{*}{ UTAN } & Danakapitasi & $32.2 \%$ \\
\hline & Danabok & $72.3 \%$ \\
\hline & Tenakesmed & $100.0 \%$ \\
\hline & Tenakeslai & $69.7 \%$ \\
\hline & Jumlahkunj & $91.3 \%$ \\
\hline & Bta & $95.3 \%$ \\
\hline & $\%$ Balita & $92.2 \%$ \\
\hline & Linakes & $95.3 \%$ \\
\hline & Imunisasid & $95.3 \%$ \\
\hline & Kbaktif & $95.3 \%$ \\
\hline
\end{tabular}

\begin{tabular}{cll}
\hline PUSKESMAS & \multicolumn{1}{c}{ VARIABEL } & ACHIEVED \\
\hline LUNYUK & Danabok & $92.7 \%$ \\
\cline { 2 - 3 } & Tenakesmed & $82.9 \%$ \\
\cline { 2 - 3 } & Tenakeslai & $100.0 \%$ \\
\cline { 2 - 3 } & Jumlahkunj & $61.2 \%$ \\
\cline { 2 - 3 } & Bta & $96.1 \%$ \\
\cline { 2 - 3 } & \%Balita & $96.1 \%$ \\
\cline { 2 - 3 } & Linakes & $94.8 \%$ \\
\cline { 2 - 3 } & Imunisasid & $96.1 \%$ \\
\cline { 2 - 3 } PUSKESMAS & KARtif & $51.5 \%$ \\
\hline \multirow{5}{*}{ UNTERIWES } & Danabok & $\mathbf{A C H I E V E D}$ \\
\cline { 2 - 3 } & Tenakesmed & $100.0 \%$ \\
\cline { 2 - 3 } & Tenakeslai & $67.8 \%$ \\
\cline { 2 - 3 } & Jumlahkunj & $96.6 \%$ \\
\cline { 2 - 3 } & Bta & $87.6 \%$ \\
\cline { 2 - 3 } & $\%$ Balita & $94.0 \%$ \\
\cline { 2 - 3 } & Linakes & $96.6 \%$ \\
\cline { 2 - 3 } & Imunisasid & $86.7 \%$ \\
\cline { 2 - 3 } & Kbaktif & $96.6 \%$ \\
& &
\end{tabular}

Sumber: Hasil Olahan DEA

\section{Kontribusi Masing-Masing Variabel Input dan Output dalam Mencapai Kondisi Efisien.}

Berdasarkan tabel 3, semua variabel output tidak mencapai skor efisiensi maksimum 100\%. Untuk meningkatkan skor efisiensi puskesmas Moyo Hilir harus meningkatkan variabel output yang besarnya dapat dilihat pada kolom "to gain". kolom "target" menunjukkan besarnya penyesuaian dari setiap variabel yang dinyatakan dalam satuan masing-masing. Misalnya untuk variabel output jumlah kunjungan harus ditingkatkan sebesar 9.9\% x nilai actual=2.371,84. Dengan 
demikian, nilai target adalah $26.329,8$ orang $(23.958+2.371,84)$. Artinya untuk mencapai skor efisiensi jumlah kunjungan harus ditingkatkan sebesar $9.9 \%$. Cakupan TB Paru BTA harus ditingkatkan sebesar 9.9\% x nilai actual $=6.1182$, dengan demikian nilai target adalah 67.9\% (61. 8+6.1182). Artinya untuk mencapai skor efisiensi variabel cakupan TB Paru BTA harus ditingkatkan sebesar 9.9\%. Perhitungan yang sama juga berlaku bagi variabel output cakupan balita ditimbang dari actualnya sebesar $75.5 \%$ menjadi $83 \%$ atau melakukan peningkatan sebesar $9.9 \%$, cakupan persalinan ditolong tenaga kesehatan dari actualnya sebesar $87.1 \%$ menjadi $95.7 \%$ atau melakukan peningkatan sebesar $9.9 \%$, cakupan imunisasi dasar dari actualnya sebesar $81.3 \%$ menjadi sebesar $89.4 \%$ atau melakukan peningkatan sebesar $9.9 \%$, cakupan $\mathrm{KB}$ aktif dari actualnya sebesar $78.1 \%$ menjadi sebesar $91.2 \%$ atau melakukan peningkatan sebesar $16.7 \%$.

Selain variabel output, perlu juga dilakukan penyusuaian pada variabel input agar tercapai skor efisiensi maksimum di puskesmas Moyo Hilir. Misalnya untuk variabel input dana bantuan operasional kesehatan dari hasil perhitungan DEA terlihat adanya kelebihan dalam pengalokasiannya sehingga harus dilakukan pengurangan sebesar $16.1 \%$ x nilai actual $=35.985 .874,75$ Dengan demikian, nilai target adalah 187.528.875,2 (223514750-35.985.874,75). Artinya untuk mencapai skor efisiensi dana bantuan operasional kesehatan harus dikurangi sebesar 16.1\%. Perhitungan yang sama juga berlaku bagi variabel input tenaga kesehatan medis sebanyak 3 orang menjadi 2 orang atau melakukan penurunan sebesar $24.3 \%$, tenaga kesehatan lainnya dari 41 orang menjadi 33 orang atau melakukan pengurangan sebesar $18.7 \%$.

Berdasarkan tabel 3, semua variabel output tidak mencapai skor efisiensi maksimum $100 \%$. Untuk meningkatkan skor efisiensi puskesmas Plampang harus meningkatkan variabel output yang besarnya dapat dilihat pada kolom "to gain". kolom "target" menunjukkan besarnya penyesuaian dari setiap variabel yang dinyatakan dalam satuan masing-masing. Misalnya untuk variabel output jumlah kunjungan harus ditingkatkan sebesar $8.6 \%$ x nilai aktual=2.390,7. Dengan demikian, nilai target adalah $30.190,7$ orang $(27800+2.390,7)$. Artinya untuk mencapai skor efisiensi jumlah kunjungan harus ditingkatkan sebesar $8.6 \%$. Cakupan TB Paru BTA harus ditingkatkan sebesar $25.8 \%$ x nilai actual $=16.77$, dengan demikian nilai target adalah $81.8 \%(65 .+16.77)$. Artinya untuk mencapai skor efisiensi variabel cakupan TB Paru BTA harus ditingkatkan sebesar 25.8\%. Perhitungan yang sama juga berlaku bagi variabel output cakupan balita ditimbang dari actualnya sebesar $78.3 \%$ menjadi $85 \%$ atau melakukan peningkatan sebesar $8.6 \%$, cakupan persalinan ditolong tenaga kesehatan dari actualnya sebesar $86.2 \%$ menjadi $93.6 \%$ atau melakukan peningkatan sebesar $8.6 \%$, cakupan imunisasi dasar dari actualnya sebesar $69.6 \%$ menjadi sebesar $88.2 \%$ atau melakukan peningkatan sebesar $26.7 \%$, cakupan KB aktif dari actualnya sebesar $71.6 \%$ menjadi sebesar $80.1 \%$ atau melakukan peningkatan sebesar $11.9 \% \%$.

Selain variabel output, perlu juga dilakukan penyusuaian pada variabel input agar tercapai skor efisiensi maksimum di puskesmas Plampang. Misalnya untuk variabel input dana kapitasi dari hasil perhitungan DEA terlihat adanya kelebihan dalam pengalokasiannya sehingga harus dilakukan pengurangan sebesar $3.4 \% \mathrm{x}$ nilai aktual $=18.439 .804,8$ Dengan demikian, nilai target adalah 523.907.395,2 (542347200-18.439.804,8). Artinya untuk mencapai skor efisiensi dana kapitasi harus dikurangi sebesar 3.4\%. Perhitungan yang sama juga berlaku 
bagi variabel input dana bantuan operasional kesehatan dari actual sebesar Rp. 263.586.900; menjadi sebesar Rp.201.274.944,2; atau melakukan pengurangan sebesar $23.6 \%$.

Berdasarkan tabel 3, semua variabel output tidak mencapai skor efisiensi maksimum $100 \%$. Untuk meningkatkan skor efisiensi puskesmas Utan harus meningkatkan variabel output yang besarnya dapat dilihat pada kolom "to gain". kolom "target" menunjukkan besarnya penyesuaian dari setiap variabel yang dinyatakan dalam satuan masing-masing. Misalnya untuk variabel output jumlah kunjungan harus ditingkatkan sebesar $9.5 \%$ x nilai actual=606,7. Dengan demikian, nilai target adalah 6993.7 orang $(6387+606,7)$. Artinya untuk mencapai skor efisiensi jumlah kunjungan harus ditingkatkan sebesar 9.5\% . Cakupan TB Paru BTA harus ditingkatkan sebesar $4.9 \%$ x nilai aktual $=2.45$, dengan demikian nilai target adalah 52.4\%(50+2.45). Artinya untuk mencapai skor efisiensi variabel cakupan TB Paru BTA harus ditingkatkan sebesar 4.9\%. Perhitungan yang sama juga berlaku bagi variabel output cakupan balita ditimbang dari actualnya sebesar $75.9 \%$ menjadi $82.3 \%$ atau melakukan peningkatan sebesar $8.4 \%$, cakupan persalinan ditolong tenaga kesehatan dari actualnya sebesar $94.2 \%$ menjadi $98.8 \%$ atau melakukan peningkatan sebesar $4.9 \%$, cakupan imunisasi dasar dari actualnya sebesar $81.2 \%$ menjadi sebesar $85.2 \%$ atau melakukan peningkatan sebesar $4.9 \%$, cakupan KB aktif dari actualnya sebesar $79.1 \%$ menjadi sebesar $83 \%$ atau melakukan peningkatan sebesar $4.9 \%$.

Selain variabel output, perlu juga dilakukan penyusuaian pada variabel input agar tercapai skor efisiensi maksimum di puskesmas Utan. Misalnya untuk variabel input dana kapitasi dari hasil perhitungan DEA terlihat adanya kelebihan dalam pengalokasiannya sehingga harus dilakukan pengurangan sebesar $67.8 \% \mathrm{x}$ nilai actual $=494.769 .686,39$ Dengan demikian, nilai target adalah 234.979.113.6 (729.748.800-494.769.686,39). Artinya untuk mencapai skor efisiensi dana kapitasi harus dikurangi sebesar $67.8 \% \%$. Perhitungan yang sama juga berlaku bagi variabel input dana bantuan operasional kesehatan dari actual sebesar Rp. 188.083.750; menjadi sebesar Rp. 135.917.998,9; atau melakukan pengurangan sebesar $27.7 \%$, tenaga kesehatan lainnya dari 34 orang menjadi 24 orang atau melakukan pengurangan sebesar $30.3 \%$.

Berdasarkan tabel 3, semua variabel output tidak mencapai skor efisiensi maksimum $100 \%$. Untuk meningkatkan skor efisiensi puskesmas Lunyuk harus meningkatkan variabel output yang besarnya dapat dilihat pada kolom "to gain". kolom "target" menunjukkan besarnya penyesuaian dari setiap variabel yang dinyatakan dalam satuan masing-masing. Misalnya untuk variabel output jumlah kunjungan harus ditingkatkan sebesar $63.3 \%$ x nilai actual=7.559,28. Dengan demikian, nilai target adalah $19.501,2$ orang $(11.942+7.559,28)$. Artinya untuk mencapai skor efisiensi jumlah kunjungan harus ditingkatkan sebesar $63.3 \%$. Cakupan TB Paru BTA harus ditingkatkan sebesar 4\% x nilai actual=2,824 dengan demikian nilai target adalah $73.4 \%(70,6+2,824)$. Artinya untuk mencapai skor efisiensi variabel cakupan TB Paru BTA harus ditingkatkan sebesar $4 \%$. Perhitungan yang sama juga berlaku bagi variabel output cakupan balita ditimbang dari actualnya sebesar $86.3 \%$ menjadi $89.8 \%$ atau melakukan peningkatan sebesar $4 \%$, cakupan persalinan ditolong tenaga kesehatan dari actualnya sebesar $82.3 \%$ menjadi $86.8 \%$ atau melakukan peningkatan sebesar $5.5 \%$, cakupan imunisasi dasar dari actualnya sebesar $77.1 \%$ menjadi sebesar $80.2 \%$ atau melakukan peningkatan 
sebesar 4\%, cakupan KB aktif dari actualnya sebesar $40.5 \%$ menjadi sebesar $78.6 \%$ atau melakukan peningkatan sebesar $94.2 \% \%$.

Selain variabel output, perlu juga dilakukan penyusuaian pada variabel input agar tercapai skor efisiensi maksimum di puskesmas Lunyuk. Misalnya untuk variabel input dana kapitasi dari hasil perhitungan DEA terlihat adanya kelebihan dalam pengalokasiannya sehingga harus dilakukan pengurangan sebesar $25 \% \mathrm{x}$ nilai actual $=95.031 .000$ Dengan demikian, nilai target adalah 285.093.000 (380.124.000-95.031.000). Artinya untuk mencapai skor efisiensi dana kapitasi harus dikurangi sebesar $25 \%$. Perhitungan yang sama juga berlaku bagi variabel input dana bantuan operasional kesehatan dari actual sebesar Rp. 169.372.900; menjadi sebesar Rp. 156.955.074,9; atau melakukan pengurangan sebesar 7.3\%, tenaga kesehatan medis dari 3 orang menjadi 2 orang atau melakukan pengurangan sebesar $17.1 \%$.

Berdasarkan tabel 3, semua variabel output tidak mencapai skor efisiensi maksimum 100\%. Untuk meningkatkan skor efisiensi puskesmas Unteriwes harus meningkatkan variabel output yang besarnya dapat dilihat pada kolom "to gain". kolom "target" menunjukkan besarnya penyesuaian dari setiap variabel yang dinyatakan dalam satuan masing-masing. Misalnya untuk variabel output jumlah kunjungan harus ditingkatkan sebesar $3.5 \%$ x nilai actual=1.186,7. Dengan demikian, nilai target adalah $35.093,7$ orang $(33.907+1.186,7)$. Artinya untuk mencapai skor efisiensi jumlah kunjungan harus ditingkatkan sebesar $3.5 \%$. Cakupan TB Paru BTA harus ditingkatkan sebesar $14.2 \%$ x nilai actual $=9,826$ dengan demikian nilai target adalah 79.1\% $(69.2+9,826)$. Artinya untuk mencapai skor efisiensi variabel cakupan TB Paru BTA harus ditingkatkan sebesar 14.2\%. Perhitungan yang sama juga berlaku bagi variabel output cakupan balita ditimbang dari actualnya sebesar $71.7 \%$ menjadi $76.2 \%$ atau melakukan peningkatan sebesar $6.3 \%$, cakupan persalinan ditolong tenaga kesehatan dari actualnya sebesar $91.2 \%$ menjadi $94.4 \%$ atau melakukan peningkatan sebesar 3.5\%, cakupan imunisasi dasar dari actualnya sebesar $74.1 \%$ menjadi sebesar $85.5 \%$ atau melakukan peningkatan sebesar $15.3 \%$, cakupan KB aktif dari actualnya sebesar $90 \%$ menjadi sebesar 93.2\% atau melakukan peningkatan sebesar 3.5\%.

Selain variabel output, perlu juga dilakukan penyusuaian pada variabel input agar tercapai skor efisiensi maksimum di puskesmas Unteriwes. Misalnya untuk variabel input dana kapitasi dari hasil perhitungan DEA terlihat adanya kelebihan dalam pengalokasiannya sehingga harus dilakukan pengurangan sebesar $32.2 \% \times$ nilai aktual $=155.258 .611,2$ Dengan demikian, nilai target adalah 326.910.988,8 (482.169.600-95.031.000). Artinya untuk mencapai skor efisiensi dana kapitasi harus dikurangi sebesar $32.2 \%$. Perhitungan yang sama juga berlaku bagi variabel input dana bantuan operasional kesehatan dari actual sebesar Rp. 191.510.500; menjadi sebesar Rp. 162.729.306,3; atau melakukan pengurangan sebesar $15 \%$, tenaga kesehatan lainnya dari 53 orang menjadi 36 orang atau melakukan pengurangan sebesar $32.2 \%$.

Tabel 3. Kontribusi masing-masing variabel input dan output dalam mencapai kondisi efisien.

\begin{tabular}{cllll}
\hline PUSKESMAS & VARIABEL & ACTUAL & TARGET & TO GAIN \\
\hline MOYO Hilir & Danakapitasi & 467568000.0 & 467568000.1 & $0.0 \%$ \\
\cline { 2 - 5 } & Danabok & 223514750.0 & 187468596.7 & $16.1 \%$ \\
\cline { 2 - 5 } & Tenakesmed & 3.0 & 2.0 & $24.3 \%$ \\
\hline
\end{tabular}




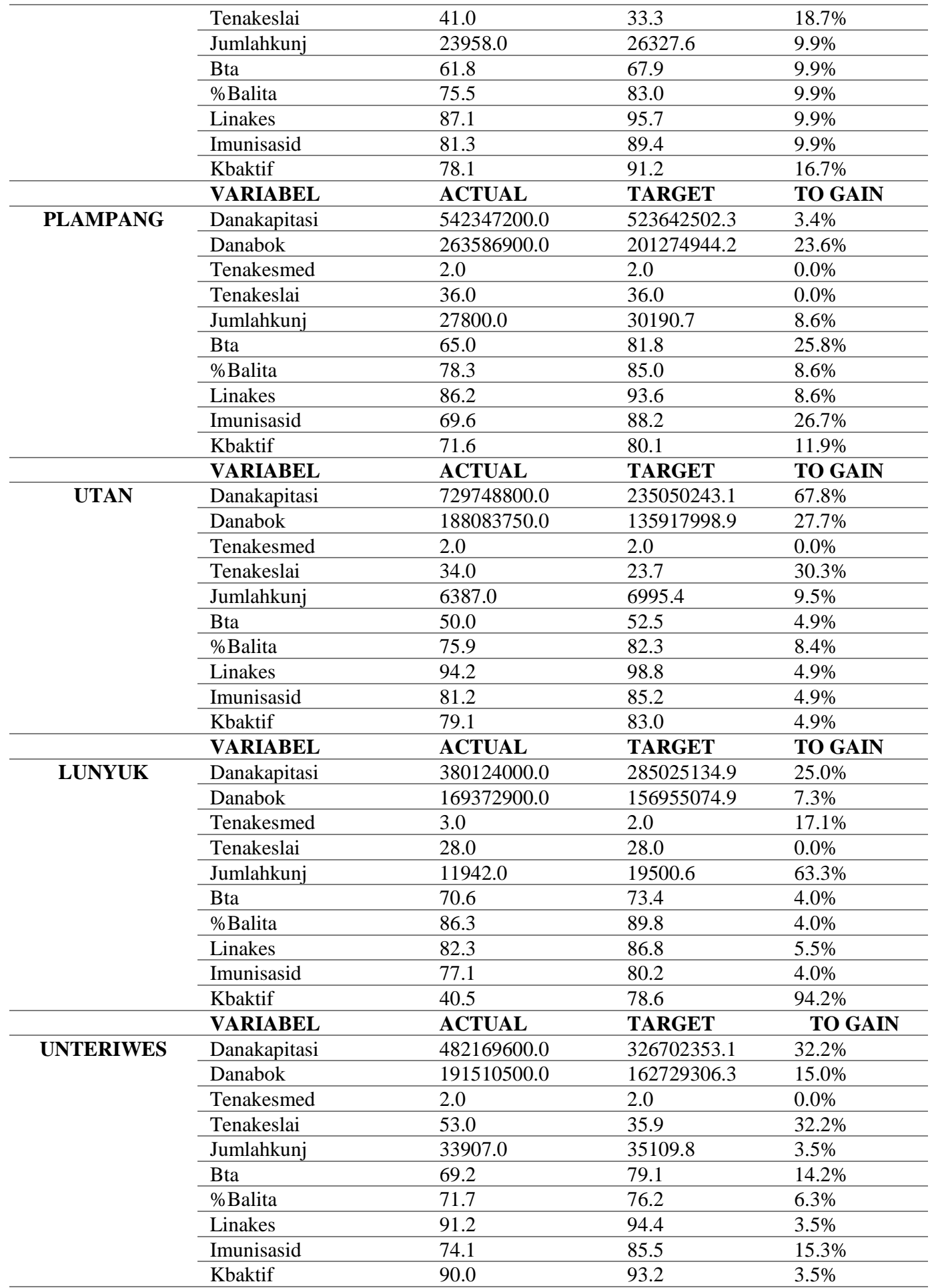

Sumber: Hasil Olahan DEA, Data sekunder, diolah

Berdasarkan uraian penjelasan di atas dapat disimpulkan bahwa secara relatif ukuran efisiensi dapat ditentukan oleh kemampuan unit kerja dalam memaksimalkan output dan meminimalkan input. Sehingga untuk memperbaiki tingkat efisiensi relative pada puskesmas dapat dilakukan baik dari sisi input maupun output. Kondisi ini dalam teori yang telah diuraikan sebelumnya, serta sejalan dengan pendapat Suswinarno (2013:149) dikatakan efisien apabila 
perusahaan atau unit kerja dalam kegiatannya menghasikan output yang maksimal dengan input tertentu. Kombinasi ini terjadi pada saat kurva isocost menyinggung kurva isoquant yaitu kurva yang menggambarkan gabungan dari factor produksi yang digunakan dapat menghasilkan satu tingkat produksi tertentu (Coelli, 1996; Rusydiana, 2003).

Hasil penelitian tersebut diatas sejalan dengan pendapat Akazili dkk. (2008) di Ghana Inefisien terjadi selain output yang tidak maksimal juga karena adanya penggunaan sumber daya yang tidak perlu/berlebihan. Alvarado (2007) berpendapat efisien akan tercapai dengan meningkatkan/memaksimalkan output. Kemudian Osei et al. (2005) berpendapat anggaran yang relative besar pada puskesmas tidak selalu dapat membantu puskesmas tersebut mencapai kondisi yang efisien, strategi dan promosi kesehatan yang harus ditingkatkan untuk mencapai skor efisien. Oleh karena itu diperlukan kebijakan yang mengkaji efisiensi puskesmas dalam pencapaian tingkat hasil, untuk itu diperlukan pengaturan yang lebih berkombinasi yang berorientasikan hasil. Untuk lebih mengoptimalkan output perlu lebih ditingkatkan lagi pelayanan puskesmas yang bukan hanya focus pada pelayanan kuratif saja, puskesmas juga harus melakukan upaya promotif dan preventif.

Dalam upaya peningkatan mutu layanan di Puskesmas, Dinas Kesehatan memiliki posisi strategis sebagai fasilitator. Sebagai fasilitator, Dinas Kesehatan diharapkan dapat memfasilitasi kebutuhan Puskesmas dalam upayanya untuk meningkatkan mutu layanan yang tidak mampu dipenuhi oleh Puskesmas sendiri, seperti kebutuhan tenaga, sarana fisik, alat, perbekalan kesehatan serta konsultasi. Setiap kegiatan di Dinas Kesehatan diupayakan dalam rangka mendukung upaya yang dilakukan Puskesmas.

\section{KESIMPULAN}

Berdasarkan analisis dan pembahasan yang telah dijelaskan pada bab sebelumnya maka dapat disimpulkan beberapa hal sebagai berikut: Dari penghitungan analisis efisiensi dengan DEA model BCC (asumsi VRS) orientasi output diperoleh dari 23 puskesmas di Kabupaten Sumbawa tahun 2015 terdapat 18 puskesmas yang efisien $(78,3 \%)$, sementara 5 puskesmas lainnya $(21,7 \%)$ nilai efisiensinya berada dibawah $100 \%$ atau tidak efisien. Rata-rata nilai efisiensi dari puskesmas-puskesmas di Kabupaten Sumbawa tahun 2015 adalah 98.74\%.

Penyebab ketidakefisienan pada puskesmas yang skor efisiennya dibawah $100 \%$ adalah seluruh unit output/variabel output meliputi: Jumlah kunjungan, Cakupan TB Paru BTA, Cakupan balita ditimbang, Cakupan persalinan ditolong tenaga kesehatan, Cakupan imunisasi dasar, Cakupan KB aktif. Selain itu kelebihan belanja/dana dan tenaga kesehatan pada variabel input meliputi: Dana kapitasi, Dana bantuan operasional kesehatan, Tenaga kesehatan medis, Tenaga Kesehatan lainnya juga menjadi sumber ketidakefisienan pusksemas tersebut.

Variabel output dapat berkontribusi untuk mencapai kondisi efisien yaitu dengan melakukan peningkatan/penyusuaian variabel output hingga mencapai target.Variabel input berkontribusi untuk mencapai kondisi efisien yaitu dengan melakukan pengurangan/penyusuaian terhadap kelebihan pada variabel input hingga mencapai target. 


\section{DAFTAR RUJUKAN}

Abidin, Z. (2009). Kinerja Efisiensi Teknis Bank Pembangunan Daerah: Pendekatan Data Envelopment Analysis(DEA). Jurnal Akuntansi dan Keuangan, 11(1), 21-29.

Akazili. J., Adjuik, M., Chatio, S., Kanyomse, E., Hodgson, A., Aikins, M., \& Gyapong, J. (2008). What are The Technical and Allocative Efficiencies of Public Health Centres in Ghana. Ghana Medical Journey, 42(4), 149-155.

Alvarado, J. R. (2007). Evaluating Technical Efficiency of Primary Health Care in The Local Government of Chile, Department of Business Economics, Autonomous University of Barcelona.

Banker, R. D., Charnes, A., \& Cooper, W.W. (1984). Some Models For Estimating Technical and Scale Inefficiencies in Data Envelopment Analysis. Management Sciences, 30(9), 1078-1092.

Boediono. (2013). Ekonomi Mikro. Edisi Kedua. BPFE: Yogyakarta

BPS. (2014). Kabupaten Sumbawa dalam Angka tahun 2014

Charnes, A., Cooper, W.W., \& Rhodes, E. (1978). Measuring the efficiency of Decision Maing Units. European Journal of Operational Research, 2, 429444.

Coeli, T.J., \& Rao. D.S.P. (2005). Total Factor Productivity Growth in Agriculture: Malmquist Index Analysis of 93 Countries, 1980-2000. Agricultural Economics, 32(1), 115-134.

Coelli T.J. (1996): A guide to DEAP version 2.0: A Data Envelopment Analysis (computer) program. enter for Efficiency and Productive Analysis (cEPA) Department of Econometrics, University of new England, Armidale, Australia.

Depkes RI, 2014. Profil Kesehatan Indonesia Tahun 2014.

Dinas Kesehatan Kabupaten Sumbawa. (2014). Profil Kesahatan Kabupaten Sumbawa Tahun 2014.

Dokumen laporan Akuntabilitas kinerja Instansi Pemerintah Kabupaten Sumbawa. 2014.

Endri. (2008). Efisiensi Teknis Perbankan Syariah di Indonesia. Finance and Banking Journal, 10(2), 136-13.

Farrell, M.J, (1957). The measurement of productive efficiency. Journal of the Royal Statistical Society, 120(3), 253-290.

Handoko, T. H. (2015). Manajemen, Cetakan Kedelapan belas. BPFE Yogyakarta, Yogyakarta

Haryadi, A. (2011). Analisis Efisiensi Teknis Bidang pendidikan (Penerapan Data Envelopment Analysis), Magister Perencanaan dan Kebijakan publik Fakultas Ekonomi Universitas Indonesia.

Idrianti, N. E. (2014). Analisis Efisiensi Belanja Daerah Di Kabupaten Sumbawa (Studi Kasus Bidang Pendidikan dan Kesehatan), Jurnal Ekonomi dan Studi Pembangunan, 6(2), 192-205.

Kalirajan, K.P., \& Shand, R.T. (1999). Frontier Production Functions and Technical Efficiency Measures. Journal of Economic Surveys, 13(2) 149-172.

Keputusan Menteri Kesehatan No.1457/Menkes/SK/X/2003 tentang Standar Pelayanan Minimal Bidang Kesehatan di Kabupaten/Kota.

Kurnia, A. S. (2006). Model Pengukuran Kinerja dan Efisiensi Sektor Publik Metode Free Disposable Hull (FDH), Jurnal Ekonomi Pembangunan, 11(2) $1-20$. 
Lena, D. P. (2007). Efisiesi Pengeluaran Pemerintah Daerah di Provinsi Jawa Tengah. Jurnal Ekonomi Pembangunan, 12(2),123-139.

Makmun. (2002). Efisiensi Kinerja Asuransi Pemerintah. Jurnal Kajian Ekonomi \& Keuangan, 6(1), 81-98.

Nugroho, R. P. (2004). Efektifitas Kinerja Pelabuhan dengan data Envelopment Analysis (DEA), jurnal manajemen Usahawan Indonesia No. 05. Th XXXIII.

Osei, D., d'Almeida, S., George, M.O., Kirigia, J.M., Mensah, A.O., \& Lenity, H.K. (2005). Technical efficiency of public district hospitals and health centres in Ghana: a pilot study 2005 retrieved from http://www.ncbi.nlm.nih.gov/pmc/articles/PMC1253524/.

Peraturan Menteri Kesehatan RI Nomor 741/MENKES/PER/VII/2008 tentang Standar Pelayanan Minimal Bidang Kesehatan di Kabupaten/Kota.

Pertiwi, L. D. (2007). Efisiensi Pengeluaran Pemerintah Daerah di Propinsi Jawa Tengah. Jurnal Ekonomi Pembangunan, 12(2),123-139.

Putri, A. (2015). Efisiensi Teknis Anggaran Belanja Sektor Kesehatan Propinsi Jawa Barat. Jurnal Signifikan, 4(2), 127-150.

Putri, V. R., \& Lulviarman, N. (2009). Pengukuran kinerja Bank Komersil dengan Pendekatan Efisiensi, Studi terhadap Perbankan Go Public di Indonesia. Jurnal Akuntansi dan Auditing Indonesia, 12(1), 41-52.

Ramanathan, R. (2003). An Introduction To Data Envelopment Analysis, Thousand Oaks, CA: Sage Publications.

Razali, R. (2012). Analisis Efisiensi Puskesmas di Kabupaten Bogor tahun 2011, Tesis MPKP FE UI.

Rusydiana, A. S. (2003). Mengukur Tingkat Efiensi dengan Data Envelopment Analisis:Teori dan Aplikasi. SMART Publishing. Bogor

Saleh, S. (2000). Data Envelopment Analysis (DEA): Konsep Dasar, PAU-SE UGM, Yogyakarta.

Sengupta, S. M. (2014). Technical Efficiency of Public Sector Banks In India Using Data Envelopment Analysis.Journal of Business and Management, 16, 5259.

Sukirno, S. (1994). Pengantar Teori Mikroekonomi (Edisi ke-3). Jakarta: raja Grafindo Persada.

Suswinarno. (2013). Mengantisipasi Resiko dalam Pengadaan Barang/Jasa Pemerintah. Jakarta: Transmedia Pustaka.

Sutawijaya, A., \& Puji, E. (2009). Efisiensi Teknik Perbankan Indonesia Pascakrisis Ekonomi: Sebuah Studi Empiris Penerapan Model DEA. Jurnal Ekonomi Pembangunan, 10(1), 49-67.

Trisnantoro, L. (2009). Memahami Penggunaan Ilmu Ekonomi dalam Manajemen Rumah Sakit, Gadjah Mada University Press. 